\title{
VULNERABILITY ASSESSMENT OF BUILDINGS BASED ON RAPID VISUAL SCREENING AND PUSHOVER: CASE STUDY OF GYOR, HUNGARY
}

\author{
ORSOLYA KEGYES-BRASSAI \\ Szechenyi Istvan University, Hungary
}

\begin{abstract}
The process of carrying out an earthquake risk assessment of a town can provide important data for authorities and disaster management to better understand risks to many buildings rather than a single building. This is even more important in the case of moderate seismic areas where any mitigation measures to be taken should be justified by seismic risk determination. Moderate seismicity does not necessarily equate to moderate damage from earthquakes. Vulnerability to earthquakes even increases with extending urban areas. Seismicity in the Pannonian Basin is moderate compared to seismicity of surrounding areas, nonetheless, reports of major earthquakes in Hungary often refer to heavy building damage and liquefaction (e.g. 1763 Komarom earthquake). Gyor was chosen to be the examined area for seismic risk analysis because it is the most important city of northwest Hungary with a large number of monumental buildings and a complex geological and geographical settings. In order to make the best use of limited resources usually characteristic to moderate seismic zones, the presented method used existing soil data, rapid visual screening of buildings, a limited number of field tests and free, but sophisticated, software. This paper focuses on the results of vulnerability analysis of buildings; however, it considers the results of seismic hazard and local site effects based on response analysis with more than 6000 realizations. Vulnerability of the buildings with different structural types were evaluated based on a rapid visual screening of 5000 building. Vulnerability based on visual screening was compared to a pushover analysis of the typical constructions. As one would expect, since the hazards and vulnerabilities were not uniformly distributed in the city districts of Gyor, there were zones of higher and lower risk. These results can then serve as useful tools for decision makers and can be applied directly to risk management plans.
\end{abstract}

Keywords: vulnerability assessment, rapid visual screening, pushover.

\section{INTRODUCTION}

The research presented in this case study estimates the seismic risk based on seismic hazard evaluation [1] and building vulnerability functions however this paper focuses on the results of vulnerability assessment. The goals of the research were: to present the process of seismic risk evaluation of a city; to integrate local site effects to previously determined seismic hazards for Hungary (National Annex of EC8) [2]; to examine the vulnerability of the built environment focusing on residential and public buildings; and finally to combine the results and map risk scenarios to aid in the mitigation process. As one would expect, since the hazards and vulnerabilities were not uniformly distributed around the examined area, there were zones of higher and lower risk [3]. Based on these risk assessments, engineers and planners can decide where to improve buildings, whether to permit further development, and formulate emergency response plans in case of a seismic event.

The next quote clearly states the importance of the work in seismic risk assessment: "The fundamental role of the seismic risk assessment for the society is to provide all the information for each community or organizations to support the risk mitigation decisionmaking. These decisions are generally related to the likelihood and significance of structural collapse to the life-safety or business interruption. Hence a high risk of structural collapse is 
not accepted by the current standards and there are various methods available for making decisions to reduce that risk" [4].

Major cause of loss during an earthquake is due to the deficient seismic performance of the built environment. Catastrophic events with high socio-economic impact occurred also at places with moderate seismic events with a magnitude of 6 to 6.5 (e.g. Italy 2009 and 2016). New standards and regulations have been applied to new structures from the beginning of 21 st Century, which represent only a small part of existing structures. In Hungary this is true also, just as it is in other parts of the world. Many existing buildings and other structures might fail to resist the earthquake and thus sustain some degree of damage that can vary from minor cracking to total collapse. Since other forms of damage and loss are generally defined as a function of primary structural damage, the starting point is to find out the expected damage due to a likely strong ground motion.

\section{METHODS USED FOR VULNERABILITY ASSESSMENT}

Vulnerability represents the link between building or structural damage and the earthquake effects and defines loss as a function of ground shaking. These functions can be developed statistically, analytically or based on expert opinions. From a probabilistic point of view, fragility functions can be derived defining the probability of some undesirable result as a function of ground shaking levels. Analogous vulnerability functions can provide a damage factor, given the intensity of the earthquake.

Vulnerability is the possibility of damage or loss of structures due to a seismic event; it is characteristic to the structure and it can be expressed in probabilistic or statistical terms. The methods to determine the vulnerability depends on the objective of the study, the required results and on available data, and can be grouped according to the space scale considered for analysis: e.g. urban level or building level, etc. [5]. Large-scale approaches are based on empirical methodologies and local scale assessments are performed using some detailed numerical analyses (Fig. 1). As these methods are getting more complex, they become more accurate, but also requiring higher computational and evaluation effort.

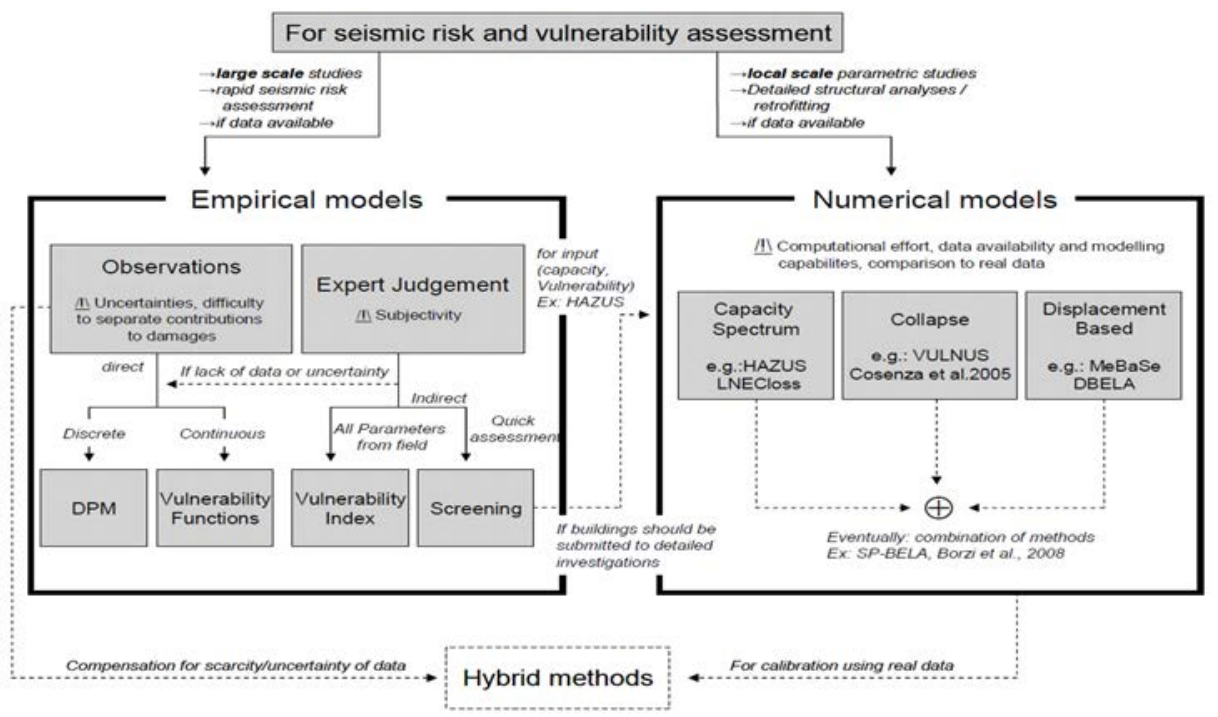

Figure 1: Schematic representation of the classical models for seismic vulnerability derived by the ENSURE project [5]. 
The rapid visual evaluation of buildings was performed on over 5000 structures. The evaluation method was developed from well-known approaches but modified to account for typical building designs found here. The reliability of the visual evaluations performed by trained non-experts was verified by experts over a significant percentage of all buildings.

Empirical methodologies are widely used to quickly assess the seismic risk on a large scale or to sort out structures that need more detailed analysis. Observed vulnerability refers to data about damages of past earthquake. In the case of observed vulnerability [6], [7] the damage is defined with the repair cost as a ratio of the amount of loss of all affected elements as a ratio of their value. The relation between damage and earthquake intensity is valid only for the region where it was developed. The vulnerability of structures can also be evaluated through expert opinions. Experts have to estimate the expected percentage of damage caused by a given intensity, which are implied in macroseismic scales.

Method used for this research was the score assignment procedure aiming to determine hazardous structures by identifying structural deficiencies. The screening methods gather quantitative information, by using vulnerability forms including parameters, such as quality of materials, type of foundations, number of stories, or stiffness of the structure. Depending on the parameter's value, a score is attributed to each feature to quantify the level of damage according to the severity of potential ground motion. Potential structural deficiencies are identified from observed correlations between damage and structural characteristics [8].

As an alternative to empirical methods detailed analyses can be used however these are more time-consuming assessments. Engineers may use several structural analysis methods to estimate building vulnerability to seismic loading. These methods apply equally to zones of strong, moderate, or weak seismicity. They are simply ways to quantify the ability of a structure to resist an earthquake event.

Lateral force method applies additional lateral forces to the structure and the model is analysed as a static load case. The magnitude and location of additional lateral forces are based on the intensity of the earthquake. Beams and columns are sized so that they remain in the elastic state. Modal response method assumes the structure will respond as a combination of harmonic motions. The contribution of each of these modes to the response of the structure is scaled according to its mass participation factor. The material behaviour is still elastic. Nonlinear time history analysis represents the most accurate method to evaluate structural response to earthquake loading however being the most time-consuming. The earthquake acceleration record is used as input to the base of the model and the structure's deformation, stiffness, damping, hinge formation and changes in geometry are all evaluated.

Further evaluation of building vulnerability was performed by pushover analyses. This method has become very popular to determine the non-linear capacity of a building to lateral forces. The basis of analysis is a static, deflection-controlled approach. As the structure is pushed over, its resistance increases to a peak value, then declines to a residual value. Values of deflection vs. base shear are often compared to seismic demand curves.

\section{AREA OF THE CASE STUDY}

Gyor was chosen to be the examined area for seismic risk analysis because it is the most important city of northwest Hungary. Being the capital of Western Transdanubia region has an important economic and cultural role. Gyor is referred to as the City of Waters as it lies at the confluence of the Moson-Danube, the Raba and the Rabca; not far from the main channel of the Danube. From a geological point of view Gyor lies in the eastern part of the macro region of Little Hungarian Plain, which is a deflational lowland and on the southern part the city extends to the Pannonhalmi Hills, which is a part of the Transdanubian Mountains. 
Thus the formation of the area is related to these two large regions [9]. This setting means a high variability in the local soil conditions posing a different level of seismic hazard on the different parts of the city.

Geomorphological conditions had a significant impact on the development and evolution of the town. The elevated flood-free terraces at the confluence of rivers offered a good possibility for the very first settlement. The Downtown (Belvaros) is basically the oldest part of the city with characteristic corner-balconies and narrow lanes, churches, museums are all reminders of a historic past (Fig. 2). Gyor is Hungary's second richest town in historic buildings outside Budapest making it vulnerable to earthquakes.

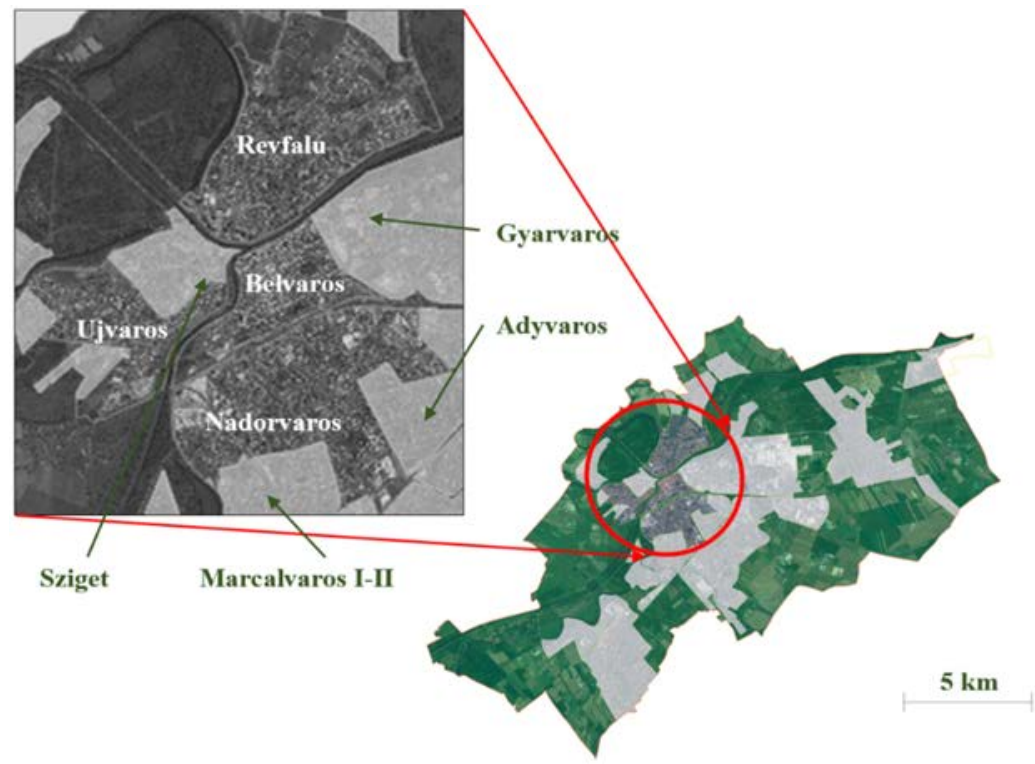

Figure 2: Historical, urban districts of Gyor.

The fact that the town is expanding to the south and east is basically due to the surface conditions. Surface water and the high-water table in every area provided adequate water supply, also for industrial purposes. The current city structure was the result of the merge of ten historical town parts. The suburb regions gradually built together with the historical city. Development of the urban areas were strongly influenced by the railway lines built in 19th Century. The industry was the key factor in the growth of several town districts such as Revfalu and Nadorvaros in that time (Fig. 2).

After the Second World War, the most striking developments took place in two areas: first, the neighbourhood villages had been attached to the city, secondly the rapid industrial development led to the creation of new industrial areas between Downtown and Gyarvaros (factory area). Accelerated urbanization enhanced the development of panel housing estates (Sziget, Gyarvaros, Adyvaros, Marcalvaros). These panel estates formed a large contiguous zone in the last fifty years of the 20th Century. They were connected with small town and suburban residential areas. Bridges built over Raba and Danube connected the districts of the city. The road network of Gyor has basically a radial structure, passed by the motorway from south. Recently, the main restructuring is the connection of the city districts, the development of the infrastructural system and the complex rehabilitation of several districts. 


\subsection{Seismicity of the area}

The seismicity of the Pannonian region is moderate (Fig. 3). Earthquakes causing light damage to occur every year, while stronger, more damaging magnitude 5 quakes happen about every 20 years and the return period of magnitude 6 events is about 100 years [10]. The distribution of earthquakes is diffuse; however, there are certain areas where the occurrence is more concentrated, e.g. at the surroundings of Komarom-Mor-Berhida, known as Mori-trench.

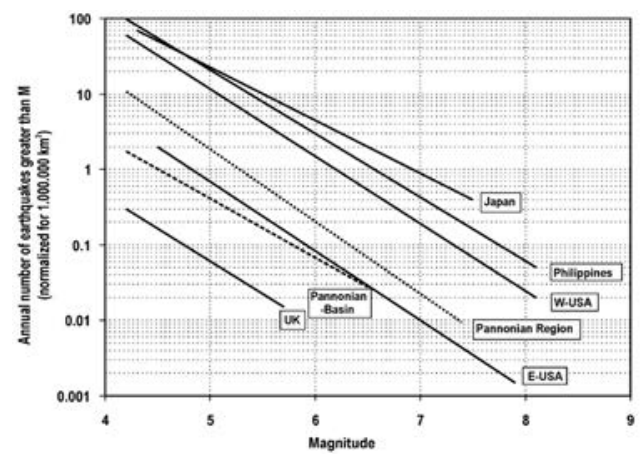

Figure 3: Annual number of earthquakes in seismically different parts of the World [10].

The largest earthquake in Hungary occurred in the city of Komárom in 1763 with an estimated magnitude of 6.3. Overall more than 100 victims were reported. The taller (2-3 story high) ecclesiastic and noble buildings with more complex structure, typical for that age, suffered serious damage, both in Komarom and Gyor, while the buildings of common people with only a ground floor made of adobe and timber survived the quakes [11]. Remedial measures were applied after the earthquake: the construction of 2-3 story high buildings were forbidden by authorities. Based on the $24 \%$ buildings destroyed, $30 \%$ seriously damaged, and $18 \%$ requiring reconstruction, the intensity can be assumed to be IX on the EMS (European Macroseismic Scale) [12].

Other significant faults contribute to the hazard concerning Gyor. One of the lineaments lies beneath the Raba River, called Raba line and meets the Diosjeno-Ogyalla or Hrubanovo fault beneath Danube River close to Gyor.

\subsection{Typical building structures}

The research focused on the residential buildings representing the highest number of building stock in Gyor. A total number of 21 city districts are grouped and presented according to the typical urban fabric. It can be differentiated between urban areas, housing estates, garden cities, and attached villages, recreational, industrial and commercial areas.

In case of residential buildings the most typical building structures are the unreinforced masonry loadbearing walls with only a ground floor with one or two flats. More intensively built housing areas were constructed in the second part of the 20th Century with one or two-story height apartment houses. Free standing buildings can be found in the urban city districts with a ground floor and 3-4 stories. The horizontal structure of these masonry buildings depends on the time of construction. After the sixties came the increased use of reinforced concrete slabs, before that time wooden structures were typical. 
The Downtown area has a typical pattern with closely constructed buildings with different heights preserving the structure of 16-17th Century. The majority of buildings are one or two-story buildings, with a significant number of built in roof spaces turned into apartment houses. Typical are the enclosed courtyard formation. The area within the former city walls has a historic importance and is a protected area. As one could expect these are the most vulnerable structures to lateral dynamic forces.

One-third of the inhabitants live in reinforced concrete large panel housing areas with 4 or 10 story height buildings. Even though the number of these buildings are much less compared to masonry structures, they behaviour is crucial in case of a seismic event because of the high number of people living in those buildings.

\section{VULNERABILITY RESULTS}

More than 5000 buildings were evaluated based on score assignment method and compared to some pushover results of typical buildings on a district level.

\subsection{Score assignment results}

Vulnerability of buildings were investigated according to FEMA 155, however the checklist was created based on literature concerning inventories for score assignment, and the knowledge about the most-used building construction of the area. First the buildings need to be classified according to their possible performance. A simplified model often neglects some of the positive influence of structural elements because they may only be present in some buildings and not others of the same classification. Building inventory with more than 5000 buildings were established based on the screening evaluation of trained staff. The checklist consists of questions about:

- General data of each building (age and function of the buildings, regularity in plan and elevation, position of the building, changes in function, previous damages, etc.)

- Structural data of each building (construction system, quality of materials, workmanship)

- Other specific items

Based on classification and the data of each building base structural scores were assigned. Score modifiers were taken into account, such as:

- Vertical irregularity score modifier;

- Construction code score modifier;

- Score modifier concerning the height of the building;

- Soil score modifier.

The construction time determined the level of seismic design used at the construction of each building. Based on the height of buildings two categories were taken into account: low-rise building with no modifier and mid-rise buildings. Vertical irregularity was based on the questionnaire.

Resulting scores could be mapped for each individual building. However from an administrative view, this would be problematic since evaluation, retrofit, repair, and planning efforts would be applied by district, or perhaps sub-district. The city districts provide a good way to categorize building structures, in general, since each district has a predominant building type and construction era. Using a district approach is quite common in risk analysis; however some decisions are necessary about how to assign a district score. One may pick a dominant structure type, either by building count (small residential buildings would have 
more influence) or total resident occupancy (apartment houses would have more influence). The average score for the dominant structure would then be applied to the district. Another approach is to use an unweighted or weighted average of all the buildings in the district.

For this study, both the dominant building approach and the average score approach produced essentially the same result. Table 1 represents the data of 4 city districts and also the results of Structural Hazard Scores for two scenarios.

Table 1: FEMA structural scores in different city districts.

\begin{tabular}{|c|c|c|c|c|c|}
\hline \multicolumn{5}{|l|}{ Town parts } & \multirow[t]{2}{*}{ Total } \\
\hline Function of the area & Belvaros & Nadorvaros & Ujvaros & Revfalu & \\
\hline $\begin{array}{l}\text { Economic, commercial, } \\
\text { industrial }\end{array}$ & $2.51 \%$ & $30.23 \%$ & $8.34 \%$ & $1.49 \%$ & \\
\hline $\begin{array}{l}\text { Special (cultural, } \\
\text { educational, ecclesiastic) }\end{array}$ & $69.79 \%$ & $14.72 \%$ & $5.94 \%$ & $9.57 \%$ & \\
\hline Rural residential & - & $7.69 \%$ & $50.25 \%$ & $36.97 \%$ & \\
\hline Garden city residential & - & $29.74 \%$ & $15.11 \%$ & $34.49 \%$ & \\
\hline Urban residential & $4.89 \%$ & $12.46 \%$ & $0.40 \%$ & $0.14 \%$ & \\
\hline Total area [ha] & 90.49 & 256.37 & 117.39 & 263.81 & 728 \\
\hline Number of residents & 10358 & 20130 & 4397 & 6640 & 41525 \\
\hline Soil profile & $\mathrm{C} 1$ & $\mathrm{C} 1 / \mathrm{C} 2 / \mathrm{C} 5$ & $\mathrm{C} 2 / \mathrm{C} 5$ & $\mathrm{C} 1 / \mathrm{C} 3$ & \\
\hline $\begin{array}{l}\text { Basic structural hazard } \\
\text { score }\end{array}$ & 2.7 & 4.2 & 4.2 & 4.2 & \\
\hline Modifier of soil & -0.4 & -0.6 & -0.6 & -0.5 & \\
\hline $\begin{array}{l}\text { Structural hazard scores } \\
\text { scenario I }\end{array}$ & 2.3 & 3.6 & 3.6 & 3.7 & \\
\hline $\begin{array}{l}\text { Structural hazard scores } \\
\text { scenario II }\end{array}$ & 0.7 & 2.0 & 2.0 & 2.1 & \\
\hline
\end{tabular}

Fig. 4 shows the distribution of the Structural Hazard Scores. A score below 2.0 means a vulnerable building with a need of an individual evaluation. Since the EC8 requirements with higher demand for designing against earthquake loads is in use only from the beginning of 20 th century these results are aligned with expectations.

Figs 5 and 6 represents the number of buildings and the scores of buildings for the district of Nadorvaros, respectively.

Masonry buildings dominate the final scores of the districts with two peaks: the lower score for the irregular buildings and higher for regular buildings. Lower scores represent higher vulnerability.

\subsection{Pushover analysis results}

Vulnerability functions were determined for typical layouts in case of masonry and reinforced concrete buildings (Fig. 7). The steps of the pushover analysis have the same order in case of both masonry and reinforced concrete building taking into account building material features respectively. With the given value of possible PGA the expectable damage can be estimated. 
PII-70 Earthquake Resistant Engineering Structures XII

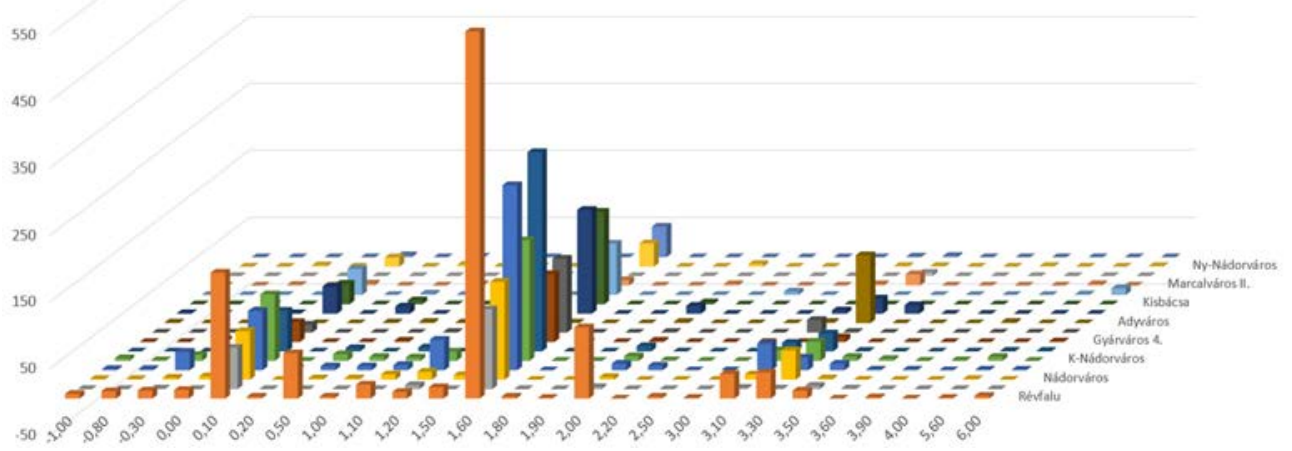

Figure 4: Distribution of structural hazard scores.

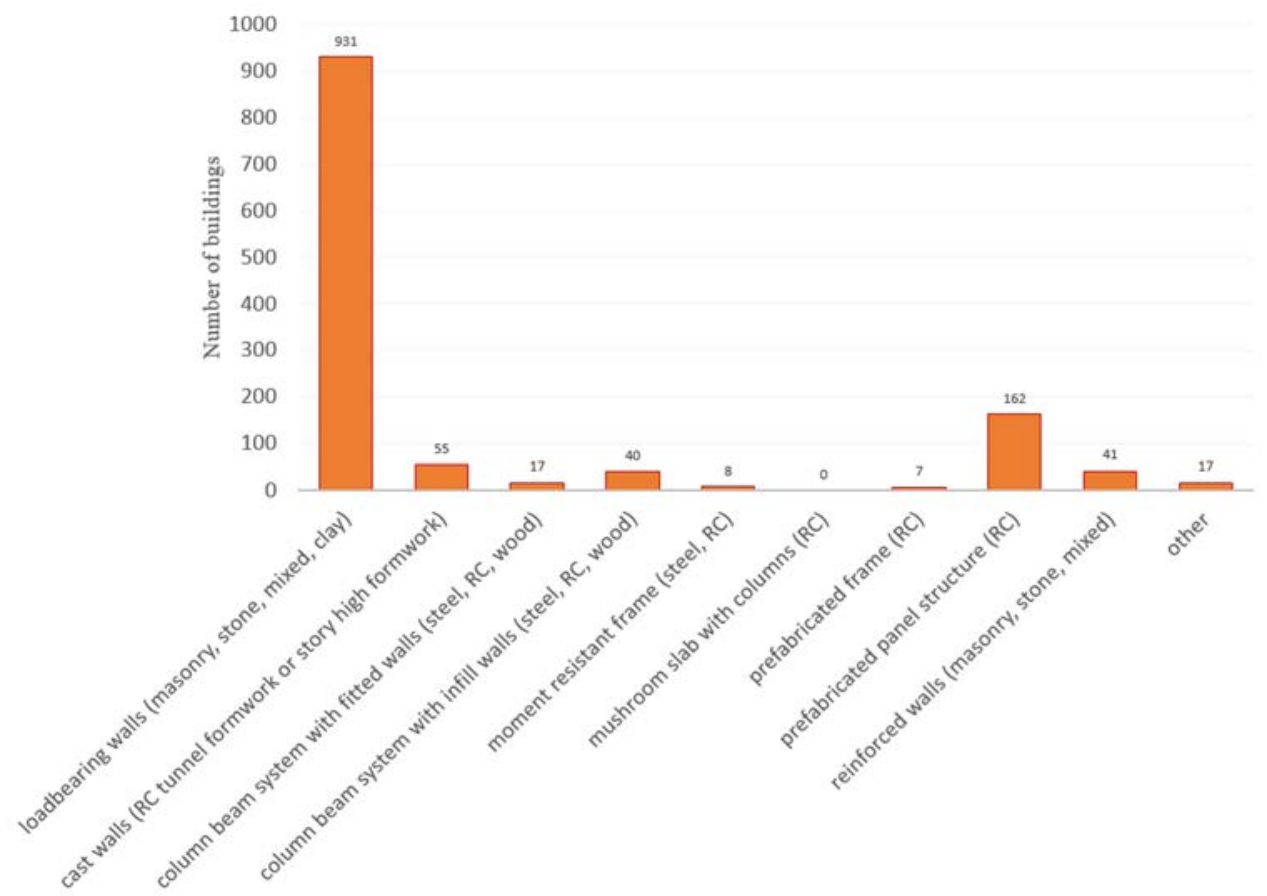

Figure 5: Number of building structures in Nadorvaros. 


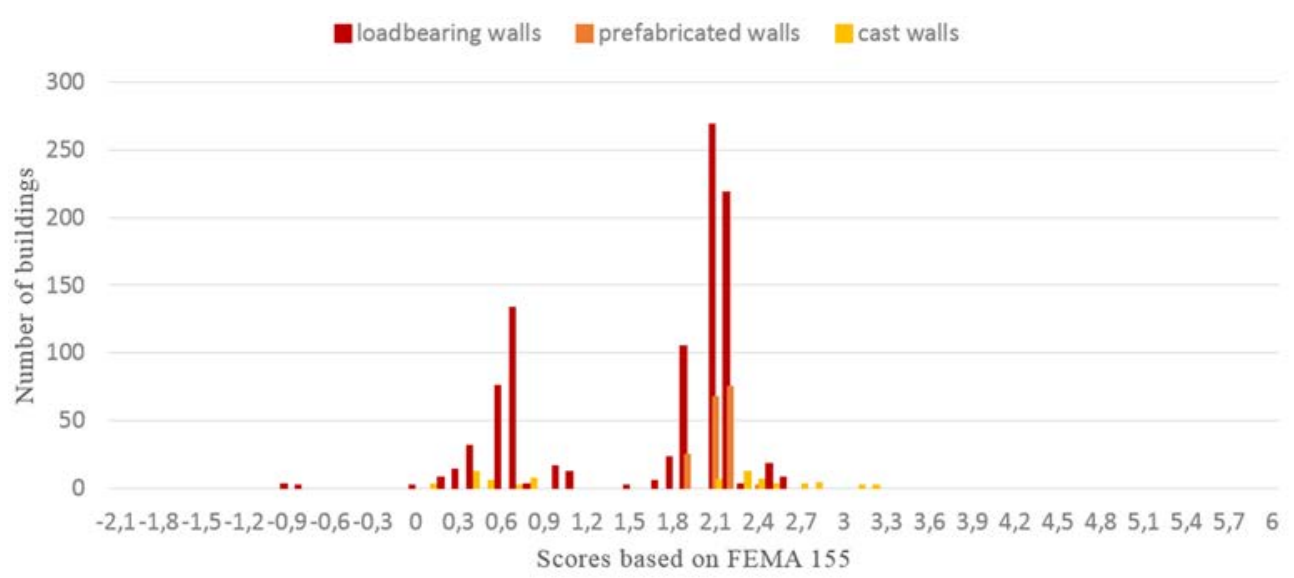

Figure 6: Structural hazard score for buildings in Nadorvaros.

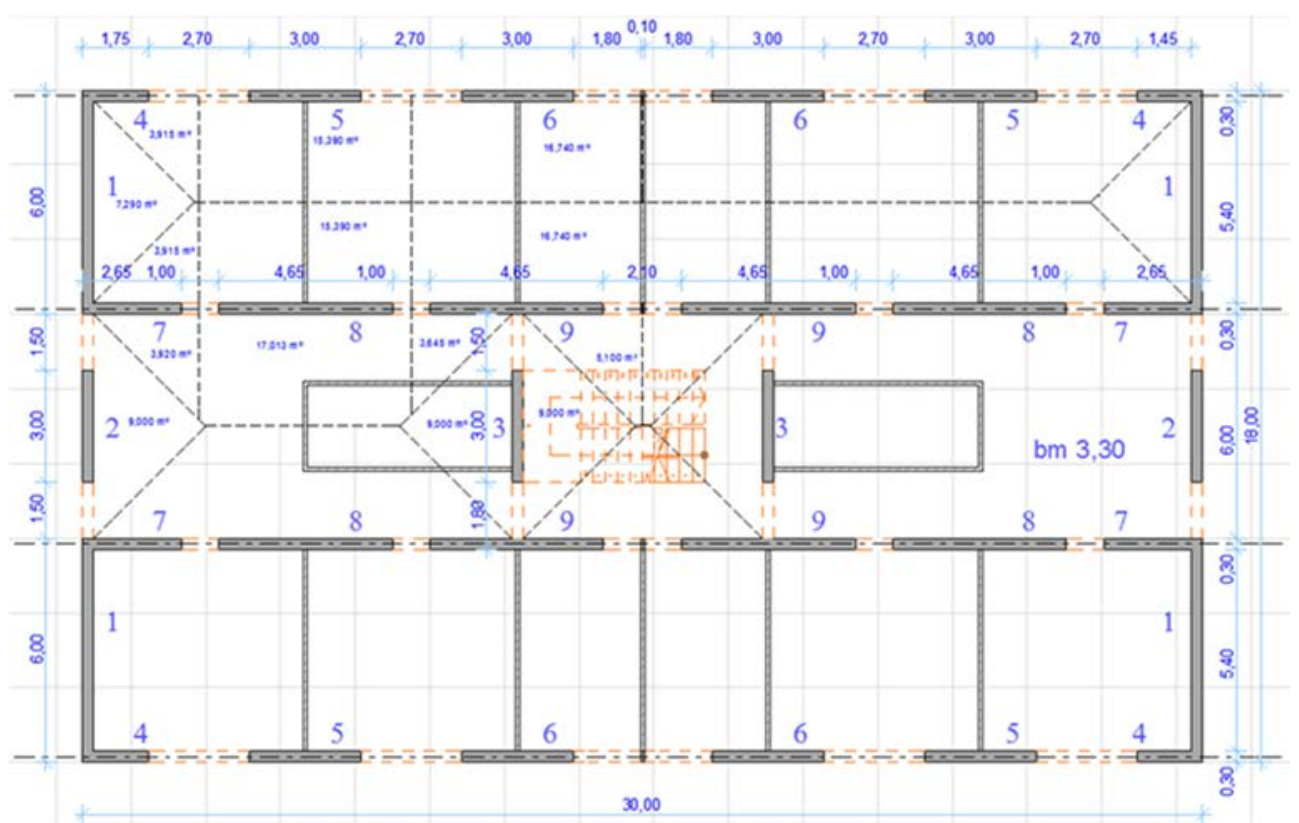

Figure 7: Layout of a typical reinforced concrete building.

All structural elements, which contribute to the loadbearing capacity of the building should be taken into account. According to the bilinear approximation the capacity curve of a wall element can be characterized by three elements: the maximum shear strength of the wall element, the nominal yield displacement $\left(\Delta_{y}\right)$ at the top of the wall and the ultimate displacement $\left(\Delta_{\mathrm{u}}\right)$ at the top of the wall. The transition between the linear elastic and perfectly plastic region is called the yield point even if masonry structures do not yield. Summarizing the shear capacities of the separate walls the shear capacity of the whole building can be obtained (Fig. 8). 


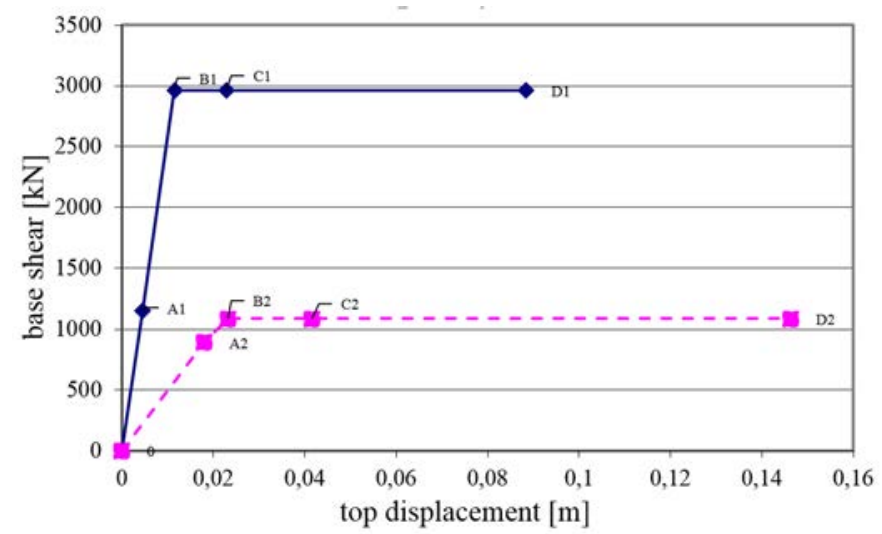

Figure 8: Capacity of the wall elements of the examined reinforced concrete building.

Material properties:

$$
\begin{array}{llll}
\mathrm{f}_{\mathrm{y}}\left[\mathrm{kN} / \mathrm{m}^{2}\right] & 500000 & & \\
\mathrm{f}_{\mathrm{c} 0^{\prime}}\left[\mathrm{kN} / \mathrm{m}^{2}\right] & 33000 & \text { Es }\left[\mathrm{kN} / \mathrm{m}^{2}\right] & 210000000 \\
\mathrm{f}_{\mathrm{c} 0^{\prime}}\left[\mathrm{kN} / \mathrm{m}^{2}\right] & 33000 & \mathrm{E}_{\mathrm{c}}\left[\mathrm{kN} / \mathrm{m}^{2}\right] & 30000000
\end{array}
$$

The main task is to obtain the vulnerability function of the building. This requires the identification of the damage grades. In the European Macroseismic Scale [12] five grades are differentiated from slight damage to total destruction allowing the identification of the points were the capacity curve of the building enters the next damage grade (Fig. 9).

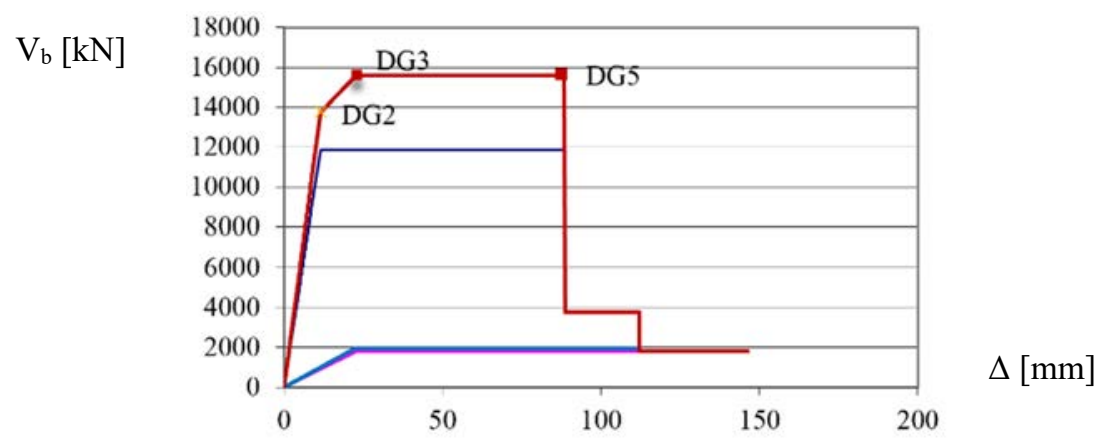

Figure 9: Capacity of the examined reinforced concrete building.

The seismic demand is determined using an elastic acceleration response spectrum (Fig. 10). It represents the maximum response of equivalent single degree of freedom system as a function of their frequencies. The spectral displacement should be compared with the displacement capacity of the building.

Based on the known PGA value the top displacement of the building can be determined. From the vulnerability function (Fig. 11) it can be read the level of damage the building would suffer in case of seismic event. 


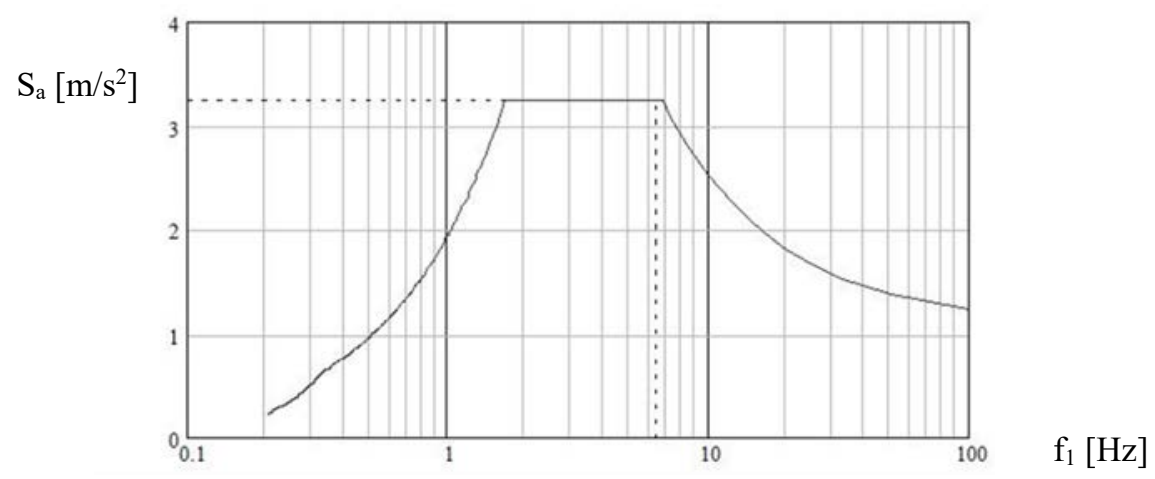

Figure 10: Spectral acceleration demand for the examined reinforced concrete building.

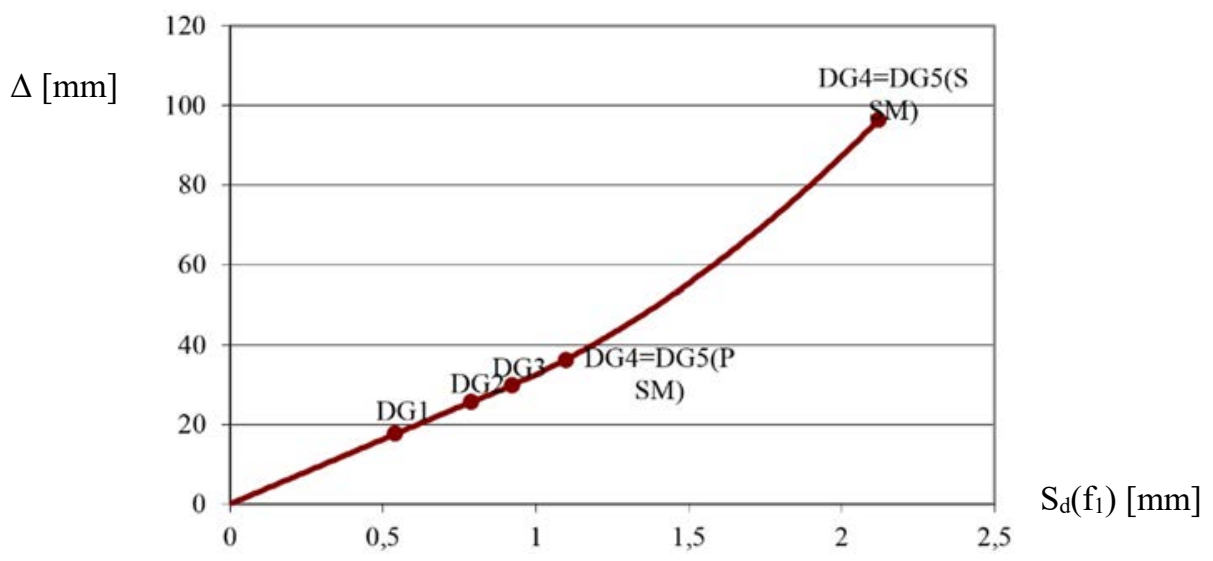

Figure 11: Vulnerability function of the examined reinforced concrete building.

\section{CONCLUSION}

The rapid visual evaluation of buildings was performed on over 5000 structures in Gyor. The evaluation method was developed from well-known approaches but modified to account for typical building designs found here. Further evaluation of building vulnerability was performed by pushover analyses by simplified methods. The analyses showed that the vulnerability assessments were consistent and reasonable.

\section{ACKNOWLEDGEMENT}

The research was supported by the EFOP-3.6.1-16-2016-00017 project: "Internationalization, initiatives to establish a new source of researchers and graduates, and development of knowledge and technological transfer as instruments of intelligent specializations at Szechenyi University".

\section{REFERENCES}

[1] Kegyes-Brassai, O.K. \& Ray, R.P., Comparison of the 1D response analysis results of typical Hungarian soil types and the EC8 spectra based on a case study of seismic risk 
analysis in Gyor. Earthquake Resistant Engineering Structures X, ed. C.A. Brebbia, WIT Press: Southampton and Boston, pp. 111-122, 2015.

[2] GeoRisk Earthquake Engineering Ltd., Seismic Hazard Map of Hungary, 2006. http://georisk.hu/. Accessed on: 3 May 2014.

[3] Kegyes-Brassai, O., Ray, R.P. \& Kuti, R., Seismic risk and disaster management perspectives in Hungary, presented on a case study performed in Gyor. Academic and Applied Research in Military and Public Management Science, 16(2), pp. 5-16, 2017.

[4] ETH Zurich, European Facility for Earthquake Hazard and Risk, 2013. http://portal.share-eu.org:8080/jetspeed/portal/. Accessed on: 13 May 2014.

[5] Foerster, E., Krien, Y., Dandoulaki, M. \& Priest, S.J., Del. 1.1.1: Methodologies to assess vulnerability of structural systems. ENSURE (Enhancing Resilience of Communities and Territories Facing Natural and Na-tech Hazards) Project WP1: State-of-the Art on Vulnerability Types s.l., European Commission Seventh Framework Programme, pp. 1-139, 2009.

[6] Castano, J.C. \& Zamarbide, J.L., A seismic risk reduction program for Mendoza City, Argentina. Tenth World Conference on Earthquake Engineering, International Association for Earthquake Engineering, Madrid, Spain, 1992.

[7] Haddar, F.N., Urban seismic vulnerability analysis: The case of Algeria. Proceedings of the. Tenth World Conference on Earthquake Engineering, International Association for Earthquake Engineering, Madrid, Spain, 1992.

[8] FEMA, 2002. FEMA 155: Second Edition, Rapid Visual Screening of Buildings for Potential Seismic Hazards: Supporting Documentation, Federal Emergency Management Agency: Washington, DC, 2002.

[9] Göcsei, I., 2.1 Győr természeti adottságai (Natural endowments of Győr). Győr Megyei Jogú településrendezési eszközeinek felülvizsgálata 2003-2005 (Evaluation of Settlement Assets in Győr), Győr Megyei Jogú Város Önkormányzata: Győr, 2005.

[10] Tóth, L., Mónus, P., Zsíros, T. \& Kiszely, M., Seismicity in the Pannonian Region Earthquake data. European Geosciences Union Stephan Mueller Special Publication Series, 3, pp. 9-28, 2002.

[11] Varga, P., Az 1763. évi komáromi földrengés (The Komárom Earthquake of 1763). Természet Világa, 145(2), 2014.

[12] Grünthal, G., European Macroseismic Scale 1998, European Seismological Commission: Luxembourg, 1998. 